\title{
KAJIAN MUTU IKAN SUNGLIR (Elagatis bipinnulatus) SEGAR DI PASAR TUMINTING MANADO
}

\author{
Arnolis Urbasa, Verly Dotulong, dan Lena J. Damongilala
}

Fakultas Perikanan dan Ilmu Kelautan, Universitas Sam Ratulangi, Manado, Sulawesi Utara.

\begin{abstract}
ABSTRAK
Ikan Sunglir (Elagatis bipinnulatus) adalah salah satu jenis ikan yang dijual di Pasar Tuminting, ikan ini digemari karena mempunyai rasa yang enak, selain itu harganya juga dapat dijangkau oleh masyarakat. Seperti ikan segar lainnya, ikan Sunglir juga mudah mengalami penurunan mutu yang mengarah kepada pembusukan, sehingga harus dilakukan penanganan yang baik selama berada dalam rantai pemasaran sampai ke tangan konsumen. Oleh karena itu perlu dilakukan penelitian tentang kajian mutu ikan Sunglir yang diambil pada waktu yang berbeda di pasar Tuminting.

Penelitian ini bertujuan mempelajari tingkat kesegaran ikan Sunglir yang dijual di pasar Tuminting. Berdasarkan Penelitian menunjukkan nilai rata-rata TVB-N ikan Sunglir segar yang dijual di pasar Tuminting tertinggi ditemukan pada ikan yang diambil siang hari pada pedagang $1(23,76 \mathrm{mg}-$ $\mathrm{N} / 100 \mathrm{~g}$ sampel), sedangkan nilai TVB-N terendah ditemukan pada ikan sunglir yang diambil sore hari pada pedagang $2(18,55 \mathrm{mg}-\mathrm{N} / 100 \mathrm{~g}$ sampel). Namun demikian data rata-rata nilai TVB-N untuk interaksi waktu pengambilan sampel dan pedagang masih berada dibawah $30 \mathrm{mg}-\mathrm{N} / 100 \mathrm{~g}$ sampel yang artinya ikan masih aman untuk dikonsumsi. Nilai $\mathrm{pH}$ ikan sunglir yang dijual di pasar Tuminting untuk waktu pengampilan sampel dan pedagang yang berbeda masih diketegorikan ikan segar karena mempunyai nilai pH rata-rata berada diantara 5,8-5,95. Nilai organoleptik yaitu mata, insang, lendir permukaan badan, daging (warna dan kenampakan), dan tekstur terdapat korelasi positif yaitu nilai tertinggi pada ketiga pedagang terdapat pada pengambilan sampel pagi hari, selanjutnya menurun pada pengambilan sampel siang hari dan sore hari, walaupun demikian nilai organoleptik ini masih masuk kategori ikan bermutu segar dan agak segar yaitu $>6$.
\end{abstract}

Kata kunci: Ikan Sunglir ((Elagatis bipinnulatus), kajian mutu, pH, TVB-N, Organoleptik.

\section{PENDAHULUAN}

Indonesia dan beberapa negara Asean lainnya menjadi penyumbang sebesar $60-70 \%$ dari kebutuhan protein hewani masyarakat. Karena itu, ikan merupakan salah satu sumber makanan yang sangat dibutuhkan.Ikan juga diketahui memiliki kandungan eicosa pentaenoic acid (EPA) dan docosa hexaenoic acid (DHA) yang adalah asam lemak omega-3 yang dapat membantu perkembangan otak dan mencegah terjadinya beberapa penyakit seperti penyakit jantung (Afrianto dan Liviawaty 1989).

Kelemahan sifat daging ikan adalah mudah busuk dimana setelah ikan mati akan mengalami perubahan-perubahan sampai akhirnya ikan tersebut dinyatakan busuk dan ditolak sebagai makanan. Perubahan tersebut umumnya disebabkan oleh adanya aktifitas enzim yang berasal dari jaringan ikan itu sendiri maupun enzim yang berasal dari bakteri yang menyebabkan terjadinya degradasi protein, lemak dan senyawa-senyawa yang lebih sederhana yaitu senyawa-senyawa basa menguap yang bisa dideteksi melalui uji "Total
Volatile Base Nitrogen(TVB-N)" (Anggawati, 2001). Penurunan pH setelah ikan mati menambah aktivitas enzim dalam proses glikolisis (Suwetja dkk, 2007). Pada ikan yang masih hidup nilai $\mathrm{pH}$ mencapai 7,0 dan setelah ikan tersebut mati, $\mathrm{pH}$ mencapai 5,8 sampai 6,2 yaitu pada saat dimana terjadi kekakuan atau rigor mortis (Suwetja, 1993). Selanjutnya dijelaskan bahwa menurunnya $\mathrm{pH}$ pada daging ikan tersebut diakibatkan karena sudah tidak ada lagi oksigen yang masuk ke dalam sel-sel daging, itu sebabnya sintesa glikogen dan glikolisis akan berlangsung secara anaerobik, sehingga menghasilkan asam laktat dan ATP. Asam laktat inilah yang menyebabkan turunnya pH daging (Suwetja $d k k$., 2007). Ikan mudah mengalami pembusukan maka faktor utama yang harus mendapatkan perhatian sebelum dikonsumsi adalah mempertahankan nilai kesegaran ikan tersebut. Untuk mempertahankan nilai kesegaran ikan sebaiknya dengan cara menghambat atau menghentikan kegiatan enzim dan mikro organisme yang terdapat pada tubuh ikan serta menghindari kontaminasi (Suwetja, 1993). Pada waktu ikan masih hidup, insang dan isi perutnya sudah 
memiliki bakteri. Bakteri ini akan bertambah berlipat ganda pada tingkat akhir autolisis (llyas, 1983). Nilai kesegaran ikan dapat dipertahankan dengan cara antara lain penanganan. Penanganan ikan setelah penangkapan atau pemanenan memegang peranan penting untuk memperoleh nilai jual ikan yang maksimal. Proses pemasaran ikan sampai ke tangan konsumen akhir (untuk dikonsumsi), biasanya memerlukan waktu 1-2 hari maka untuk mempertahankan nilai kesegaran dan nilai jual ikan tersebut perlu dilakukan penanganan selama pemasaran salah satu cara adalah dengan pendinginan (Junianto, 2003). Ikan Sunglir adalah salah satu jenis ikan yang dijual di Pasar Tuminting, ikan ini digemari karena mempuyai rasa yang enak, selain itu harganya juga dapat dijangkau oleh masyarakat.

Ciri-ciri atau deskripsi ikan Sunglir (Jalanidhitah, 2014) adalah sebagai berikut: badan berbentuk bulat panjang, kepala dan moncong meruncing, mulut kecil, rahang atas tidak mencapai bawah depan dari mata, garis lateral melengkung sedikit kecil, sirip dada sangat pendek, dua sirip kecil berjajar di belakang sirip-sirip lemah punggung dan dubur, badan berwarna biru gelap pada punggung, mempunyai pita midlaterek yang tebal, perut berwarna putih, dan sirip-sirip gelap dengan suatu sepuhan warna kuning minyak zaitun.

Seperti ikan segar lainnya, ikan sunglir juga mudah mengalami penurunan mutu yang mengarah kepada pembusukan, sehingga harus dilakukan penanganan yang baik selama berada dalam rantai pemasaran sampai ke tangan konsumen. Oleh karena itu, perlu dilakukan penelitian tentang kajian mutu ikan sunglir yang diambil pada waktu dan pedagang yang berbeda di pasar Tuminting.

\section{METODOLOGI PENELITIAN}

\section{Tempat dan Waktu Penelitian.}

Penelitian ini dilaksanakan di

laboratorium Kimia Hasil Perikanan Fakultas

Perikanan dan Ilmu Kelautan Universitas Sam

Ratulangi Manado Kegiatan Penelitian dilaksanakan mulai bulan Oktober-Depember 2014.

\section{Bahan dan Alat Penelitian}

Bahan baku yang digunakan dalam penelitian ini adalah ikan Sunglir, dengan ukuran umumnya $30-50 \mathrm{~cm}$, berat $1-1,5 \mathrm{~kg}$.
Bahan-bahan kimia adalah es batu, Trichloro Acetic Acid (TCA) 7,5\%, $\mathrm{K}_{2} \mathrm{CO}_{3} 1 \%$, $\mathrm{HCl} 1 \%$, $\mathrm{H}_{3} \mathrm{BO}_{3} 1 \%$, buffer pH 7 dan akuades. Peralatan yang digunakan yaitu cool box, gelas ukur, gelas piala, pipet ukur, pipet tetes, mortar, cawan Conway, statif, mikroburet, inkubator, $\mathrm{pH}$ meter, dan seperangkat peralatan untuk pengujian organoleptik.

\section{Metode Penelitian}

Penelitian ini bersifat eksploratif, dimana data diolah secara dekriptif menggunakan microsoft excel pada rerata tiga variabel independen dengan standar deviasi (Sd). Perlakuan dalam penelitian ini adalah sebagai berikut. A: Waktu pengambilan sampel yang terdiri atas. $\mathrm{A}_{1}=$ Jam 06.00-07.00, $\mathrm{A}_{2}=$ Jam 11.00-12.00, $\mathrm{A}_{3}=$ Jam 17.00-18.00 B: Pedagang yang terdiri atas $\mathrm{B}_{1}=$ Pedagang $1, \mathrm{~B}_{2}$ $=$ Pedagang $2, \mathrm{~B}_{3}=$ Pedagang 3 . Ulangan dalam penelitian ini adalah 3 kali pengambilan sampel yaitu hari pertama, hari kedua, dan hari ketiga.

\section{Tata Laksana Penelitian}

Tata laksana penelitian adalah sebagai berikut: Ikan Sunglir yang dijadikan sampel dibeli dari pasar Tuminting. Ikan tersebut dimasukkan ke dalam cool box dan diberi hancuran es, selanjutnya dibawa ke Laboratorium Kimia Hasil Perikanan, Fakultas Perikanan dan Ilmu Kelautan UNSRAT Manado. Pengambilan sampel untuk ulangan adalah sebagai berikut: ulangan 1 yaitu pengambilan sampel hari pertama jam 06.0007.00, 11.00-12.00 dan 16.00-17.00. Pengambilan sampel untuk ulangan hari kedua dan hari ketiga dilakukan sama seperti hari pertama. Jumlah sampel yang diambil disesuaikan dengan perlakuan yang diberikan, selanjutnya sampel dibawa ke laboratorium untuk dilakukan uji $\mathrm{pH}, \quad$ TVB-N dan organoleptik.

\section{HASIL DAN PEMBAHASAN}

\section{Nilai Total Volatile Base-Nitrogen (TVB-N) (mg N/ 100g sampel)}

Nilai rata-rata uji TVB-N untuk sampel ikan Sunglir pada waktu pengambilan sampel dan pedagang yang berbeda dapat dilihat pada Gambar 1. 


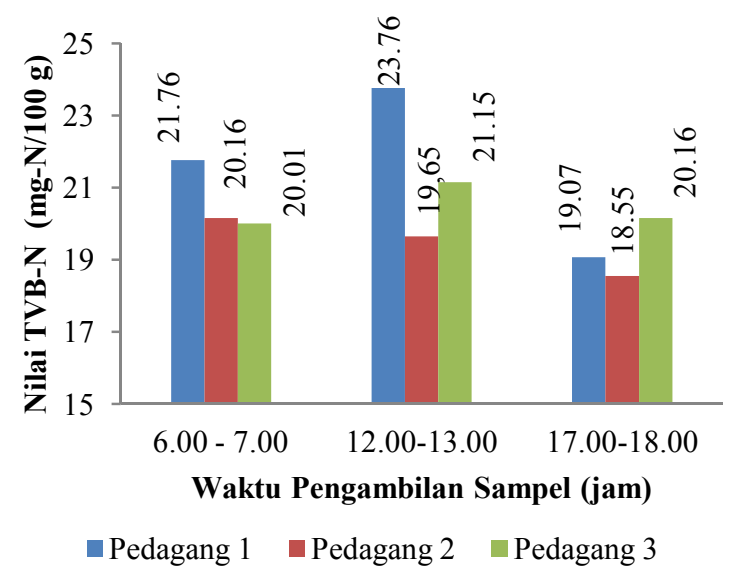

Gambar 1. Histogram hubungan waktu pengambilan sampel dan pedagang yang berbeda dengan nilai TVB-N ikan Sunglir Segar.

Gambar 1 memperlihatkan bahwa ratarata nilai TVB-N tertinggi ditemukan pada ikan sunglir yang diambil siang hari pada pedagang 1 (23,76 mg-N/100g sampel), sedangkan nilai TVB-N terendah ditemukan pada ikan sunglir yang diambil sore hari pada pedagang $2(18,55$ mg-N/100g sampel). Data ini menunjukkan bahwa mutu ikan sunglir pada pedagang di pasar Tuminting tidak seragam, hal ini kemungkinan disebabkan karena penanganan yang kurang benar yaitu peletakan es dan ikan didalam cool box tidak seragam sehingga ikan yang bersentuhan langsung dengan es akan mempunyai mutu yang lebih baik dari ikan yang letaknya tidak bersentuhan langsung dengan es. Data rata-rata nilai TVB-N untuk interaksi waktu pengambilan sampel dan pedagang masih berada dibawah $30 \mathrm{mg}-\mathrm{N} / 100 \mathrm{~g}$ sampel, Hal ini berarti ikan tersebut masih aman untuk dikonsumsi. Menurut Connel (1990), dalam Pongoh (2001), batas kandungan TVB-N ikan yang masih dapat diterima oleh konsumen adalah sebesar $30 \mathrm{mg}$ N/100 g sampel. Data hasil uji nilai TVB-N ini sesuai dengan hasil uji nilai $\mathrm{pH}$, yaitu untuk semua interaksi perlakuan nilai $\mathrm{pH}$ berkisar 5,8 - 5,95, dimana nilai $\mathrm{pH}$ ini menunjukkan ikan sunglir yang diambil di Pasar Tuminting masih dikaterogikan ikan segar.

\section{Nilai pH}

Pengukuran $\mathrm{pH}$ adalah prosedur yang di gunakan dalam uji biokimia, karena menentukan banyak peranan penting dari aktivitas enzim,(Suwetja, 1993). Rata-rata hasil uji $\mathrm{pH}$ untuk sampel ikan Sunglir pada waktu pengambilan sampel dan pedagang yang berbeda dapat dilihat pada Gambar 2. Gambar ini memperlihatkan bahwa nilai $\mathrm{pH}$ ikan sunglir yang dijual di pasar Tuminting untuk waktu pengampilan sampel dan pedagang yang berbeda masih diketgorikan ikan segar karena mempunyai nilai $\mathrm{pH}$ rata-rata berada diantara $5,8-5,95$.

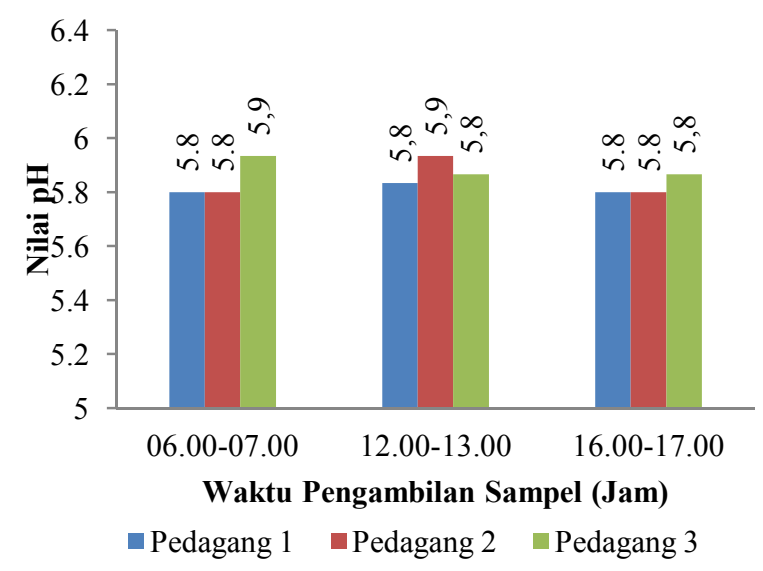

Gambar 2. Histogram hubungan waktu pengambilan sampel dan pedagang yang berbeda dengan nilai pH ikan Sunglir segar.

\section{Nilai Organoleptik Mata}

Nilai rata-rata hasil uji organoleptik mata untuk sampel ikan Sunglir pada waktu pengambilan sampel dan pedagang yang berbeda dapat dilihat pada Gambar 3. Data pada Gambar ini memperlihatkan bahwa ikan sunglir yang dijual oleh pedagang 1, 2 dan 3 mempunyai nilai organoleptik mata yang tertinggi pada waktu pengambilan sampel pagi hari yaitu7,93; 7,80 dan 7,93 yang termasuk kategori ikan segar dan berturut-turut menurun pada waktu pengambilan sampel siang hari yaitu 7,$10 ; 7,43$ dan 7,17 juga termasuk kategori ikan segar dan sore hari yaitu 6,57; 6,33 dan 6,33 yang termasuk kategori ikan agak segar. Menurut BSN (2006), berdasarkan tingkat kesegaran maka nilai organoleptik ikan dikelompokkan kedalam 3 nilai yaitu ikan segar mempunyai nilai organoleptik 7-9, ikan agak segar mempunyai nilai organoleptik 5-6 dan ikan yang tergolong tidak segar mempunyai nilai organoleptik 1-3. Nilai organoleptik seperti ini kemungkinan disebabkan karena sampel yang diambil pada pagi hari adalah sampel segar yang baru dibeli dari tempat pelelangan ikan, sisa ikan yang tidak terjual pada pagi hari disimpan dalam cool box dan dijual lagi pada siang hari, hal yang sama 
dilakukan juga untuk penjualan sore hari, hal ini menyebabkan mutu ikan menurun dari waktu penjualan pagi hari ke siang hari dan selanjutnya ke sore hari.

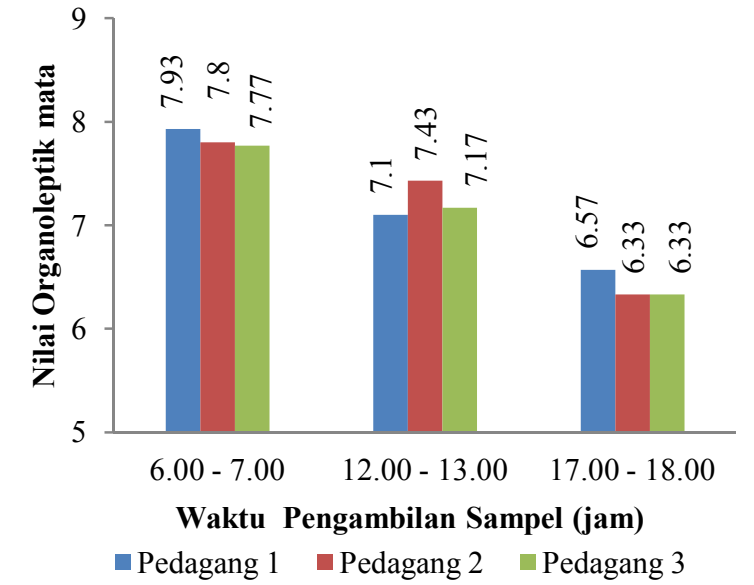

Gambar 3. Histogram hubungan waktu pengambilan sampel dan pedagang yang berbeda terhadap nilai organoleptik mata ikan Sunglir segar.

\section{Nilai Organoleptik Insang}

.Nilai rata-rata hasil uji organoleptik insang untuk sampel ikan Sunglir segar pada waktu pengambilan sampel dan pedagang yang berbeda dapat dilihat pada Gambar 4. Nilai organoleptik insang ikan sunglir pada Gambar 4 menunjukkan bahwa baik pedagang 1,2 maupun 3 mempunyai nilai tertinggi pada waktu pengambiln sampel pagi hari yaitu 7,20; 7,$63 ; 7,00$ diikuti oleh waktu pengambilan sampel siang hari yaitu 7,$00 ; 6,93 ; 6,93$ dan sore hari 6,$40 ; 6,64$; dan 6,49. Data ini mempunyai korelasi positif dengan data organoleptik mata dan lendir permukaan badan. Hal ini menunjukkan bahwa ikan sunglir yang dijual pada pagi hari adalah ikan sunglir yang baru dibeli dari tempat pelelangan ikan yang mempunyai mutu segar, sedangkan ikan sunglir yang dijual pada siang hari dan sore hari adalah ikan yang tidak laku terjual, selanjutnya disimpan dalam cool box dan dijual kembali pada siang hari dan demikian juga diperlakukan untuk ikan sunglir yang dijual pada sore hari.

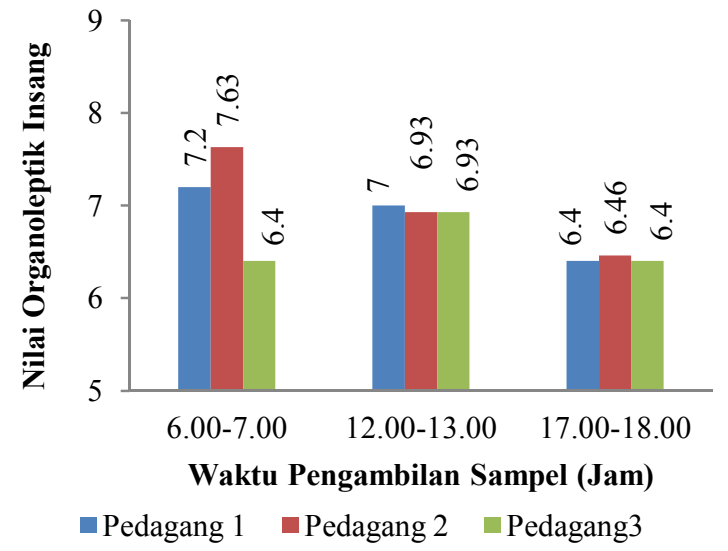

Gambar 4. Histogram hubungan waktu pengambilan sampel dan pedagang yang berbeda dengan nilai orgoanoleptik insang ikan Sunglir segar.

\section{Nilai Organoleptik Lendir Permukaan Badan.}

Nilai rata-rata hasil uji organoleptik lendir permukaan badan ikan sunglir segar pada waktu pengambilan sampel dan pedagang yang berbeda dapat dilihat pada Gambar 5. Data ini menunjukka bahwa nilai lendir permukaan badan yang diambil pada pagi hari pada pedagang 1, 2 dan 3 mempunyai nilai organoleptik yang lebih tinggi, selanjutnya menurun pada pengambilan sampel siang hari dan diikuti oleh ikan sunglir yang diambil pada sore hari. Hal ini menunjukkan bahwa nilai organoleptik lendir permukaan badan mempunyai korelasi positif dengan nilai organoleptik mata maupun insang.

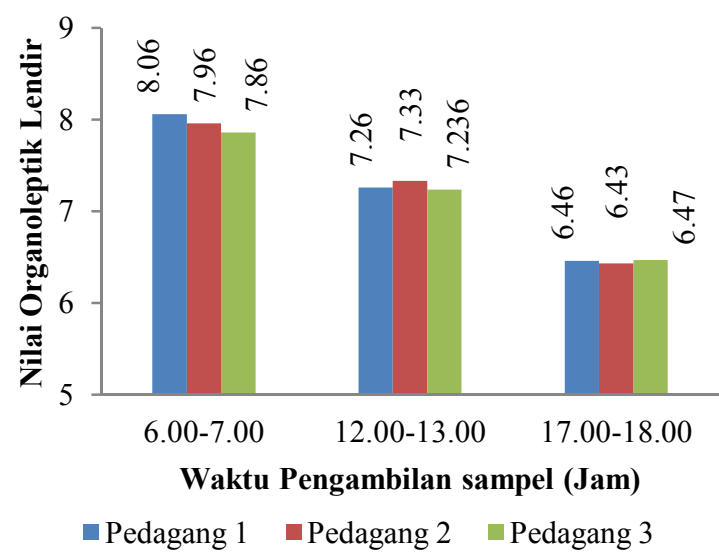
Gambar 5. Histogram hubungan waktu pengambilan sampel dan pedagang yang berbeda dengan nilai organoleptik lendir permukaan badan ikan Sunglir segar.


Nilai Organoleptik Daging (Warna dan Kenampakan) Ikan Sunglir.

Nilai rata-rata hasil uji organoleptik daging ikan Sunglir segar pada waktu pengambilan sampel dan pedagang yang berbeda dapat dilihat pada Gambar 6. Gambar ini memperlihatkan bahwa baik pedagang 1, 2 maupun 3 mempunyai data organoleptik daging (warna dan kenampakan) tertinggi terdapat pada waktu pengambilan sampel di pagi hari, selanjutnya nilai tersebut menurun untuk waktu pengambilan sampel siang hari dan sore hari. Hal ini menunjukkan bahwa ikan sunglir segar yang dijual di pasar Tuminting pada pagi hari adalah ikan yang baru tiba dari tempat pelelangan ikan, selanjutnya sisa ikan yang tidak habis terjual dipagi hari ini disimpan didalam cool box dan dijual kembali disiang hari, demikian pula untuk ikan yang dijual di sore hari.

Nilai organoleptik daging (warna dan kenampakan) memperlihatkan bahwa ikan sunglir yang diambil dipagi hari mempunyai nilai 7,66-8,06, ini artinya sayatan daging cemerlang, tidak ada pemerahan sepanjang tulang belakang dan dinding perut utuh. Ikan sunglir yang diambil pada siang hari mempunyai nilai 7,06-7,29 ini menunjukkan ikan sunglir tersebut kesegarannya sudah mulai menurun, ini artinya sayatan daging sedikit kurang cemerlang, tidak ada pemerahan sepanjang tulang belakang dan dinding perut daging utuh. Ikan sunglir yang diambil sore hari sudah mempunyai nilai yang semakin menurun yaitu 6,16-6,33. Badan Standarisasi Nasional (BSN. 2006), menyatakan bahwa nilai 7-9 masuk kategori ikan segar, sedangkan nilai 5-6 masuk kategori ikan agak segar.

\section{Nilai Organoleptik Tekstur}

Nilai rata-rata hasil uji organoleptik daging ikan Sunglir segar pada waktu pengambilan sampel dan pedagang yang berbeda dapat dilihat pada Gambar 7.

Gambar 7 memperlihatkan bahwa nilai organoleptik tekstur ikan sunglir yang dijual oleh ketiga pedagang di pasar Tuminting pada pagi hari mempunyai nilai tertinggi yaitu $7,83-$ 7,93. Nilai ini mempunyai arti tekstur agak padat, elastis bila ditekan dengan jari, sulit menyobek daging dari tulang belakang. Nilai organoleptik tekstur ikan sunglir yang dijual pada siang hari mempunyai nilai $7,13-7,27$, ini artinya tekstur agak lunak, berkas jari terlihat bila ditekan dengan jari, dan sulit menyobek daging dari tulang belakang. Nilai tektur pada tiga pedagang yang diambil pada sore hari mempunyai nilai tekstur yang semakin menurun yaitu 6,37-6,53. Hasil penelitian menunjukkan bahwa untuk semua nilai organoleptik yaitu mata, insang, lendir permukaan badan, daging (warna dan kenampakan), dan tekstur terdapat korelasi positif yaitu nilai tertinggi pada ketiga pedagang terdapat pada pengambilan sampel pagi hari, selanjutnya menurun pada pengambilan sampel siang hari dan sore hari, walaupun demikian hasil uji organoleptik ini masih masuk kategori ikan bermutu segar dan agak segar. BSN (2006), menyatakan bahwa ikan segar yang mempunyai nilai organoleptik 7-9 termasuk kategori ikan segar, sedangkan nilai 5-6 termasuk kategori ikan agak segar.

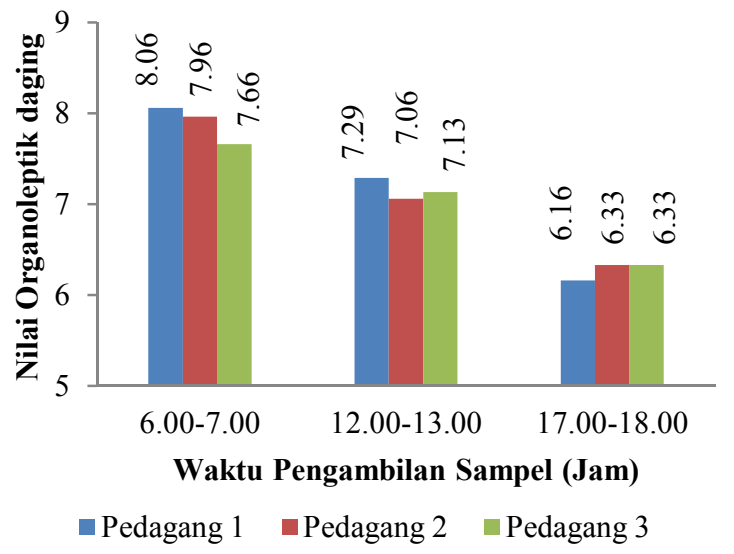

Gambar 6. Histogram hubungan waktu pengambilan sampel dan pedagang yang berbeda dengan nilai organoleptik daging ikan Sunglir segar

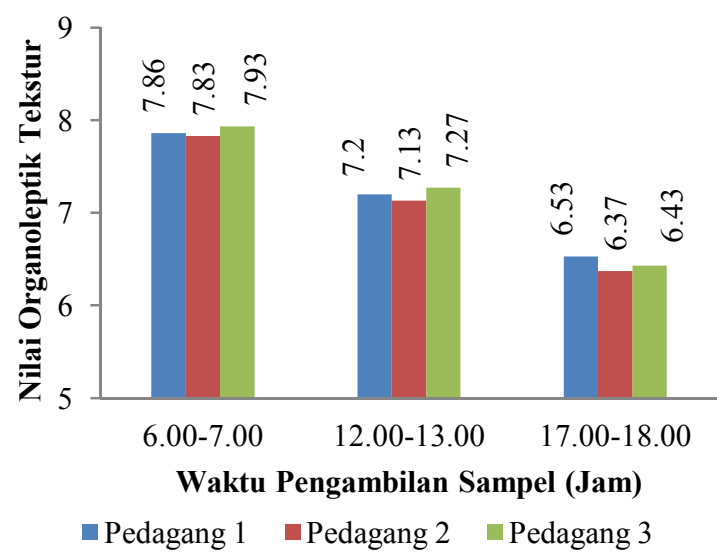

Gambar 7. Histogram hubungan waktu pengambilan sampel dan pedagang yang berbeda dengan nilai organoleptik tekstur ikan Sunglir segar. 


\section{KESIMPULAN}

Berdasarkan hasil penelitian yang diperoleh dapat ditarik beberapa kesimpulan yaitu Nilai rata-rata TVB-N ikan sunglir segar yang dijual di pasar Tuminting tertinggi ditemukan pada ikan yang diambil siang hari pada pedagang 1 yaitu $23,76 \mathrm{mg}-\mathrm{N} / 100 \mathrm{~g}$ sampel, sedangkan nilai TVB-N terendah ditemukan pada ikan sunglir yang diambil sore hari pada pedagang 2 yaitu $18,55 \mathrm{mg}-\mathrm{N} / 100 \mathrm{~g}$ sampel. Walaupun demikian data rata-rata TVB-N untuk interaksi waktu pengambilan sampel dan pedagang masih berada dibawah 30 mg-N/100g sampel yang artinya ikan masih aman untuk dikonsumsi. Nilai $\mathrm{pH}$ ikan sunglir yang dijual di pasar Tuminting untuk waktu pengampilan sampel dan pedagang yang berbeda masih diketgorikan ikan segar karena mempunyai nilai $\mathrm{pH}$ rata-rata berada diantara 5,8 - 5,95. Nilai organoleptik yaitu mata, insang, lendir permukaan badan, daging (warna dan kenampakan), dan tekstur terdapat korelasi positif yaitu nilai tertinggi pada ketiga pedagang terdapat pada pengambilan sampel pagi hari, selanjutnya menurun pada pengambilan sampel siang hari dan sore hari, walaupun demikian hasil uji organoleptik ini masih masuk kategori ikan bermutu segar dan agak segar yaitu $>6$.

\section{DAFTAR PUSTAKA}

Afrianto, E dan E. Liviawat. 1989. Pengawetan dan Pengolahan Ikan. Kanisius. Yogyakarta.

Anggawati, A. 2001. Penanganan Ikan Segar. Artikel. Departemen Kelautan dan Perikanan. Jakarta.

Anonimous, 2014. Database Ikan Indonesia. Sumberdaya Ikan, Ditjen Perikanan Tangkap Kementrian Kelautan dan Perikanan. Diunggah Tanggal 20 September 2014

Badan Standarisasi Nasional (BSN), 2006. Standar Nasional Indonesia 01- 2346. Uji Organoleptik Ikan Segar Jakarta, Badan Standarisasi Nasional Indonesia. Berhimpon, S., F. G. Ijong dan P. Moniharapon, 2002. Penilaian Indera. Penuntun Praktikum. FPIK.UNSRAT. Manado.

Ilyas .1983. Teknologi Refrigerasi Hsil Perikanan, Jilid 1. Teknik Pendinginan Ikan. Jakarta: CV Paripurna.

Junianto. 2003, Teknik Penanganan Ikan. Jakarta : Penebar Swadaya. Lay, B . W . 1994, Analisa Mikrobiologidi Laboratorium PT Raja Grafindo persada. Jakarta.

Jalanidhitah S.V. 2014. Ikan Sunglir (Elagatis bipinnulatus). Sekolah Tinggi Ilmu Perikanan. Diunggah tanggal 20 September 2014. Suwetja,I.K.. 1993. Metoda Penentuan Mutu Ika jilid I. Penentuan Kesegaran. Fakultas Perikanan Universitas Sam Ratulangi.

Suwetja I.K. 1993. Metoda Penentuan Mutu Ika jilid I. Penentuan Kesegaran. Fakultas Perikanan Universitas Sam Ratulangi. Manado

Suwetja I.K, J. Pongoh, dan Jumriah O. 2007. Penentuan Rigor Indeks, TMAO, dan ATP. Diktat. Universitas Sam Ratulangai. Manado. 